\title{
Mg-Al Mixed Oxide Adsorbent Synthesized Using FCT Template for Fluoride Removal from Drinking Water
}

\author{
Jifa Liu, Ping Zhao $(\mathbb{D}$, Yue Xu, and Xibin Jia \\ Key Laboratory of Processing and Testing Technology of Glass \& Functional Ceramics of Shandong Provincial, \\ School of Materials Science and Engineer, Qilu University of Technology (Shandong Academy of Sciences), Jinan 250353, China
}

Correspondence should be addressed to Ping Zhao; zhaoping6101@qlu.edu.cn

Received 21 December 2018; Revised 1 March 2019; Accepted 8 April 2019; Published 7 July 2019

Academic Editor: Ian S. Butler

Copyright ( 2019 Jifa Liu et al. This is an open access article distributed under the Creative Commons Attribution License, which permits unrestricted use, distribution, and reproduction in any medium, provided the original work is properly cited.

To make full use of natural waste, a novel $\mathrm{Mg}$ - $\mathrm{Al}$ mixed oxide adsorbent was synthesized by the dip-calcination method using the fluff of the chinar tree (FCT) and an $\mathrm{Mg}$ (II) and $\mathrm{Al}$ (III) chloride solution as raw materials. The adsorbents were characterized by X-ray diffraction (XRD), scanning electron microscopy (SEM), Fourier transform infrared (FT-IR) spectroscopy, and X-ray photoelectron spectroscopy (XPS). The effects of the $\mathrm{Mg} / \mathrm{Al}$ molar ratio and calcination temperature on the performance of the novel $\mathrm{Mg}$ - $\mathrm{Al}$ mixed oxide adsorbent were investigated. The optimized $\mathrm{Mg}$ - $\mathrm{Al}$ mixed oxide adsorbent had a Langmuir adsorption capacity of $53 \mathrm{mg} / \mathrm{g}$. This adsorption capacity was higher than that of the separate $\mathrm{Mg}$ oxide and $\mathrm{Al}$ oxide. The synergy between $\mathrm{Mg}$ and $\mathrm{Al}$ is beneficial to the adsorption performance of the material. The fluoride adsorption capacity of the optimized $\mathrm{Mg}$ - $\mathrm{Al} \mathrm{mixed}$ oxide adsorbent is only slightly affected by ions such as $\mathrm{Cl}^{-}, \mathrm{NO}_{3}{ }^{-}, \mathrm{SO}_{4}{ }^{2-}, \mathrm{Na}^{+}$, and $\mathrm{K}^{+}$and is excellent for use in recycling and real water. The hydroxyl groups on the surface of the $\mathrm{Mg}$ - $\mathrm{Al}$ mixed oxide adsorbent play a key role in the adsorption of fluorine. The asobtained novel $\mathrm{Mg}$-Al mixed oxide adsorbent is an efficient and environmentally friendly agent for fluoride removal from drinking water.

\section{Introduction}

Microstructure plays a vital role in determining the performance of materials. In nature, plants and organisms have formed a large number of unique microstructures through long-term evolution and natural selection. The biological template of nature provides new directions for highperformance and multifunctional materials [1]. In recent years, researchers have used biological templates to prepare a large number of high-performance materials [2]. To date, biological materials, such as spherical yeast [3], viruses [4], cotton cellulose [5], nucleotides [6], and poplar catkin [7], have been used as templates. Combining biomaterials and chemical materials is one way to use natural resources to serve humanity.

With the development of human civilization, the pollution of water resources has emerged as a main issue requiring an urgent solution. In addition, high-fluoride drinking water is harmful to human health, and the fluoride content of drinking water has exceeded the WHO standard of $1.5 \mathrm{mg} / \mathrm{L}$ in some countries [8,9]. Long-term drinking of water with excess fluoride can lead to abnormal tooth enamel in children and to joint pain and deformity of the limbs in adults [10]. Various methods of fluoride removal have their own limitations, but the adsorption method is regarded as the most promising method because of its simple process and low cost $[11,12]$. At the same time, the adsorption method is also widely used to remove other pollutants such as chromium (IV) $[13,14]$. To date, Ti(IV)modified granular activated carbon [15], cerium-containing bone char [16], activated alumina [17], Mn-Ce oxide [18], $\mathrm{Al}-\mathrm{Fe}$ (hydr)oxides [19], a magnesium-iron-aluminum trimetal composite [20], and hydrous zirconium oxide [21] have been used as fluoride adsorbents. The addition of precious metals and an increase in the complexity of the preparation techniques both increase the cost of the adsorbent, which is one of the factors hindering the use of adsorbents in developing countries. 
In recent years, activated alumina and magnesium oxides have been used widely due to their mesoporous structure, low toxicity, recyclability, and modifiability [22-27]. Sabu et al. [28] used egg shell membrane as a template to synthesize hierarchical interwoven alumina as a fluoride adsorbent. Zhang et al. [29] prepared hierarchical microstructured/nanostructured tubular $\mathrm{TiO}_{2}$ using the fluff of the chinar tree (FCT) as a biological template. The resultant material is used as a photocatalyst, and its catalytic performance is enhanced by its porous and tubular structure. In addition, FCT can easily cause skin irritation and respiratory infections. Using FCT as a biological template not only reduces its harm but also makes full use of natural resources to serve humanity. However, the literature contains few reports on the use of FCT as a biological template for the preparation of a fluoride adsorbent.

In this paper, $\mathrm{Mg}$ - $\mathrm{Al}$ mixed oxide hollow tubes were synthesized using the dip-calcination method with FCT as a biological template and with aluminum chloride and magnesium chloride as precursors without adding any precipitant. The fluoride adsorption and synergistic interactions between $\mathrm{Mg}$ and $\mathrm{Al}$ during crystallization were investigated. The adsorption mechanism of the $\mathrm{Mg}$ - $\mathrm{Al}$ bimetal mixed oxide adsorbent is discussed.

\section{Experimental}

2.1. Materials and Methods. FCT was collected from the campus of our university. Aluminum chloride, magnesium chloride, and sodium fluoride were supplied by Sinopharm Chemical Reagent Co., Ltd. The FCT was washed with deionized water after being dipped in anhydrous ethanol and $0.1 \mathrm{M}$ hydrochloric acid and was dried in an electrical drying oven at $60^{\circ} \mathrm{C}$. Oxide adsorbent powders were prepared via a dip-calcination method. The FCT was immersed in $0.3 \mathrm{~mol} / \mathrm{L}$ water solution of $\mathrm{AlCl}_{3} \cdot 6 \mathrm{H}_{2} \mathrm{O}$ and $\mathrm{MgCl}_{2} \cdot 6 \mathrm{H}_{2} \mathrm{O}$ for $24 \mathrm{~h}$ at room temperature. It was then dried in an electrical drying oven at $60^{\circ} \mathrm{C}$. The FCT loaded with aluminum chloride and magnesium chloride was placed in a corundum crucible and calcined at $400,600,800$, or $1000^{\circ} \mathrm{C}$ in a muffle furnace for $120 \mathrm{~min}$ individually. The adsorbent adsorption capacity was optimized by adjusting the calcination temperature and $\mathrm{Mg} / \mathrm{Al}$ molar ratio.

\subsection{Adsorbent Characterization. An Autosorb-iQ-MP} surface area and pore size analyzer (Quantachrome Instruments) were used to record the Brunaurer-EmmettTeller (BET) data of prepared oxide adsorbent powders at $77.35 \mathrm{~K}$ using nitrogen. The phase structure of the prepared oxide adsorbent powder was characterized by $\mathrm{CuK}_{\alpha}$ radiation with a wavelength of $\lambda=0.15418 \mathrm{~nm}$ on a SHIMADZU XRD-6100 X-ray diffractometer. The X-ray diffractometer scan range was $10-70^{\circ}$, the speed was $6^{\circ} \mathrm{min}$, and the scanning step was $0.02^{\circ}$. Scanning electron microscopy (SEM) images of the oxide adsorbent powder were obtained from a ZEISS GeminiSEM 500 field emission scanning electron microscope. The Fourier transform infrared (FT-IR) spectra of the oxide adsorbent powders before and after adsorption were recorded in the range $4000-500 \mathrm{~cm}^{-1}$ using a Thermo Scientific Nicolet iS10 FTIR spectrometer. X-ray photoelectron spectroscopy (XPS) analysis of oxide adsorbent powders before and after adsorption was conducted on a Thermo Scientific Escalab 250Xi spectrometer using an $\mathrm{Al} K_{\alpha} \mathrm{X}$-ray source $(1486.6 \mathrm{eV}$, $150 \mathrm{~W}$ ) as a constant analyzer.

2.3. Adsorption Capacity Measurements. A sodium fluoride stock solution was prepared by placing $0.2210 \mathrm{~g}$ of sodium fluoride into $1000 \mathrm{~mL}$ of distilled water. A $100 \mathrm{~mL}$ fluoride solution with a fluoride concentration of $50 \mathrm{mg} / \mathrm{L}$ was added to a plastic-sealed conical flask for an adsorption test. Afterward, $0.05 \mathrm{~g}$ of adsorbent was added to a plasticsealed conical flask containing a fluoride solution. The test solution was shaken in a thermostatic water bath shaker at $150 \mathrm{rpm}$ and kept at $30^{\circ} \mathrm{C}$ for $24 \mathrm{~h}$ [30]. The effect of coexisting $\mathrm{Cl}^{-}, \mathrm{NO}_{3}{ }^{-}, \mathrm{SO}_{4}{ }^{2-}, \mathrm{HCO}_{3}{ }^{-}, \mathrm{H}_{2} \mathrm{PO}_{4}{ }^{-}, \mathrm{Na}^{+}$, and $\mathrm{K}^{+}$ ions at concentrations of $0.1,0.4$, and $0.7 \mathrm{mg} / \mathrm{L}$ was also investigated, where $0.05 \mathrm{~g}$ of adsorbent powder was added to $100 \mathrm{~mL}$ of $50 \mathrm{mg} / \mathrm{L}$ fluoride solution. The $\mathrm{pH}$ of the solutions was adjusted by adding $0.1 \mathrm{~mol} / \mathrm{L} \mathrm{NaOH}$ or $\mathrm{HCl}$ solution. The effects of $\mathrm{pH}$ value (2-11), initial fluoride concentration $(10-100 \mathrm{mg} / \mathrm{L})$, contact time $(2-24 \mathrm{~h})$, and temperature $\left(30-50^{\circ} \mathrm{C}\right)$ on the adsorption of fluoride ion were researched, respectively. The real water sample was taken from the campus river for the fluorine removal test of the adsorbent. The adsorbent was treated with a $0.5 \mathrm{M}$ $\mathrm{NaOH}$ solution for regeneration studies. After the adsorption equilibrium, the adsorbent was separated from the solution using a centrifuge (relative centrifugal force $=3404 G$ ). The fluoride concentration was measured using an ion meter (Shanghai Instrument Electric Science Instrument Limited by Share Ltd.), and the equilibrium adsorption capacity, $q_{\mathrm{e}}(\mathrm{mg} / \mathrm{g})$, of the adsorbent was calculated from the results. The $q_{\mathrm{e}}(\mathrm{mg} / \mathrm{g})$ was calculated using the following equation:

$$
q_{\mathrm{e}}=\frac{\left(C_{0}-C_{\mathrm{e}}\right) V}{m},
$$

where $C_{0}(\mathrm{mg} / \mathrm{L})$ and $C_{\mathrm{e}}(\mathrm{mg} / \mathrm{L})$ are the initial and equilibrium concentrations of fluoride, respectively, $V(L)$ is the volume of the fluoride solution, and $m(\mathrm{~g})$ is the mass of the adsorbent [31].

\section{Results and Discussion}

3.1. Optimized $M g$-Al Mixed Oxide Adsorbent. Figure 1 shows the fluoride removal ability of the $\mathrm{Mg}-\mathrm{Al}$ mixed oxide adsorbents prepared using different $\mathrm{Mg} / \mathrm{Al}$ molar ratios and calcination temperatures (denoted as FCT-400-I, FCT-400-II, FCT-400-III, FCT-400-IV, FCT-400-V, FCT600-I, FCT-600-II, FCT-600-III, FCT-600-IV, FCT-600-V, FCT-800-I, FCT-800-II, FCT-800-III, FCT-800-IV, FCT800-V, FCT-1000-I, FCT-1000-II, FCT-1000-III, FCT1000-IV, and FCT-1000-V, respectively, where I, II, III, IV, and V represent $\mathrm{Mg} / \mathrm{Al}$ molar ratios of $1: 1,2: 1,4: 1$, 


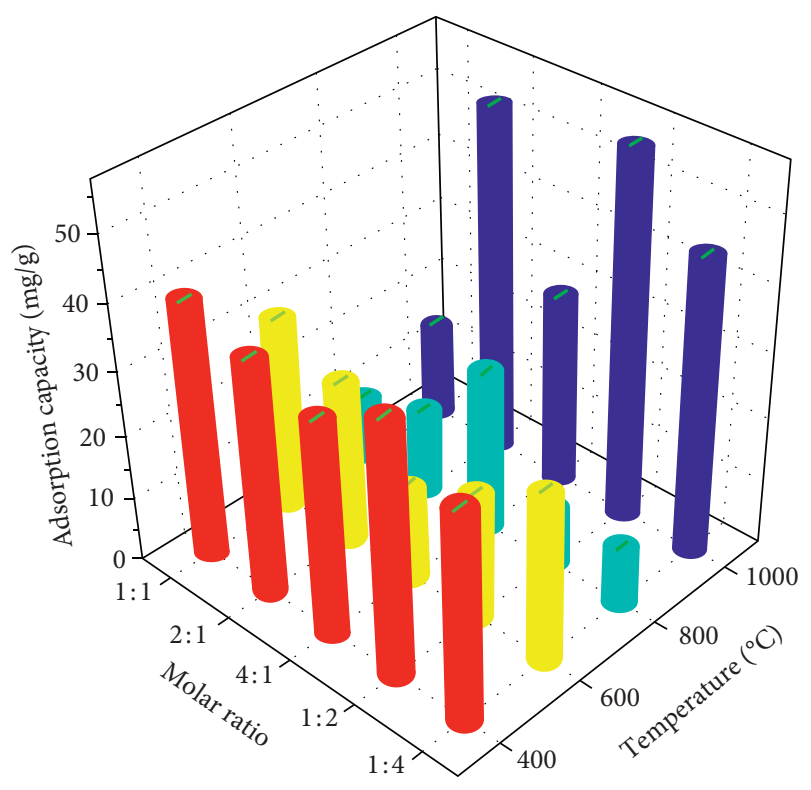

Figure 1: Comparison of the adsorption capacity of fluoride powders prepared using different $\mathrm{Mg} / \mathrm{Al}$ molar ratios and calcination temperatures (adsorbent dose: $0.5 \mathrm{~g} / \mathrm{L}$; initial concentration of $\mathrm{F}^{-}$: $50 \mathrm{mg} / \mathrm{L}$; adsorption time: $24 \mathrm{~h}$; temperature: $30^{\circ} \mathrm{C} ; \mathrm{pH}$ : neutral conditions).

$1: 2$, and $1: 4$, respectively). As the calcination temperature increases, the adsorption capacity of the $\mathrm{Mg}$ - $\mathrm{Al}$ mixed oxide adsorbent powder prepared using different $\mathrm{Mg} / \mathrm{Al}$ molar ratios first decreases and then increases. This behavior is attributable to the grains growing and the surface adsorption active sites covering each other as the temperature increases, followed by the crystal grains being twice crystallized, which caused the grains to be mutually displaced and the adsorption active sites to be re-exposed when the temperature was raised to $1000^{\circ} \mathrm{C}$. The optimum $\mathrm{Mg}$ - $\mathrm{Al}$ mixed oxide adsorbent powder was (FCT-1000-IV) prepared using a $\mathrm{Mg} / \mathrm{Al}$ molar ratio of $1: 2$ and a calcination temperature of $1000^{\circ} \mathrm{C}$.

The fluoride adsorption isotherm of the FCT-1000-IV $\mathrm{Mg}$-Al mixed oxide adsorbent powder was studied; the results are shown in Figure 2. The maximum adsorption capacity of the FCT-1000-IV adsorbent is $53 \mathrm{mg} / \mathrm{g}$ (Figure 2). This adsorption capacity is comparable to that of the $\mathrm{Mg} / \mathrm{Fe}$-layered double hydroxide in Table 1 but is higher than the capacities of the other materials. According to the correlation coefficient $\left(R^{2}\right)$ given by the Langmuir and Freundlich equations, the Freundlich model is more suitable for describing the adsorption behavior, indicating that the adsorption may be due to multimolecular layer adsorption [36]. By comparison, the $\mathrm{Mg}-\mathrm{Al}$ mixed oxide adsorbent prepared using a $\mathrm{Mg} / \mathrm{Al}$ molar ratio of $1: 2$ and a calcination temperature of $1000^{\circ} \mathrm{C}$ exhibits the highest fluoride adsorption capacity. The $\mathrm{N}_{2}$ adsorption-desorption isotherm of the obtained product calcined at $1000^{\circ} \mathrm{C}$ is shown in Figure 3. The isotherm is type $\mathrm{V}$ with a $\mathrm{H} 3$ hysteresis loop, suggesting a mesoporous structure [37]. The BET surface area and average pore diameter are $45.5 \mathrm{~m}^{2} / \mathrm{g}$ and $28.19 \mathrm{~nm}$, respectively.

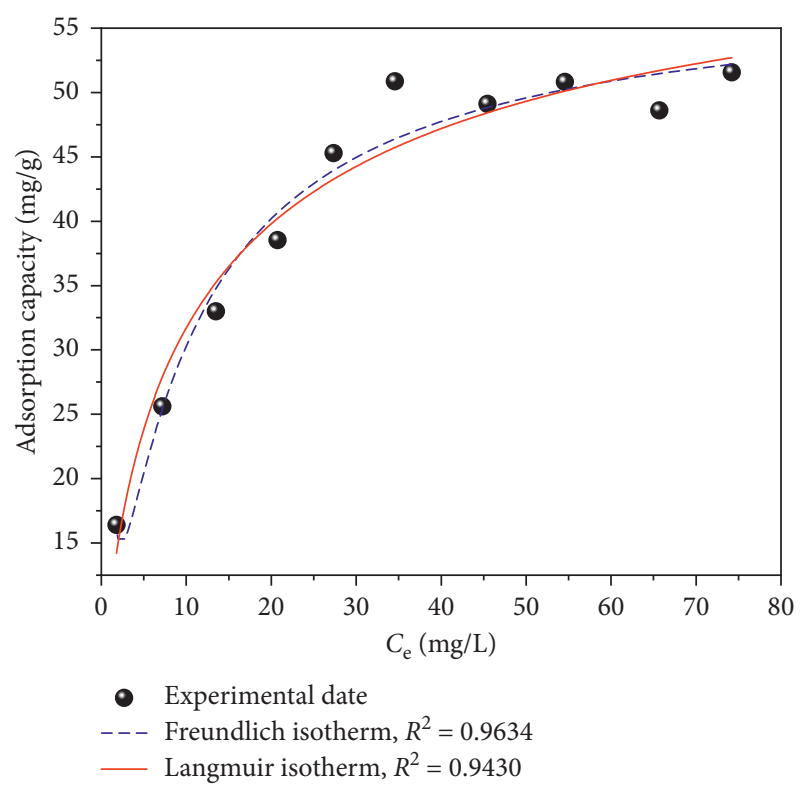

FIGURE 2: Adsorption isotherms of fluoride on FCT-1000-IV adsorbent powder (adsorbent dose: $0.5 \mathrm{~g} / \mathrm{L}$; initial concentration of $\mathrm{F}^{-}: 10-100 \mathrm{mg} / \mathrm{L}$; adsorption time: $24 \mathrm{~h}$; temperature: $30^{\circ} \mathrm{C} ; \mathrm{pH}$ : neutral conditions).

TABle 1: Comparison of the fluoride adsorption capacity of the $\mathrm{Mg}$-Al mixed oxide adsorbent with other adsorbents.

\begin{tabular}{lcccc}
\hline Adsorbents & $\begin{array}{c}C_{0} \\
(\mathrm{mg} / \mathrm{L})\end{array}$ & $\begin{array}{c}\text { Adsorbent } \\
\text { dose }(\mathrm{g} / \mathrm{L})\end{array}$ & $\begin{array}{c}q_{\mathrm{e}} \\
(\mathrm{mg} / \mathrm{g})\end{array}$ & References \\
\hline $\begin{array}{l}\text { MgO mesoporous } \\
\text { nanofibers }\end{array}$ & - & 0.6 & 237.49 & {$[32]$} \\
$\begin{array}{l}\text { Mg/Fe-layered } \\
\text { double hydroxides }\end{array}$ & - & 1 & 50.91 & {$[33]$} \\
$\begin{array}{l}\text { Al-Ce hybrid } \\
\text { adsorbent }\end{array}$ & $2-15$ & 0.1 & 27.5 & {$[30]$} \\
$\begin{array}{l}\text { Mg-Al-Zr composite } \\
\begin{array}{l}\text { Amorphous } \\
\text { aluminum hydroxide }\end{array}\end{array}$ & $10-105$ & 1 & 22.9 & {$[31]$} \\
$\begin{array}{l}\text { hollow spheres } \\
\text { Mg-Al-Fe compound }\end{array}$ & - & 0.2 & 14 & {$[35]$} \\
$\begin{array}{l}\text { Mg-Al mixed oxide } \\
\text { 10-100 }\end{array}$ & 0.5 & 53 & This work \\
\hline
\end{tabular}

Figure 4 shows the XRD patterns of the $\mathrm{Mg}$ - $\mathrm{Al}$ mixed oxide adsorbent calcined at different temperatures (FCT400-IV, FCT-600-IV, FCT-800-IV, and FCT-1000-IV). The $\mathrm{Mg}-\mathrm{Al}$ mixed oxide adsorbent maintained an amorphous phase when the calcination temperature was $400^{\circ} \mathrm{C}$. When the calcination temperature was increased to $600^{\circ} \mathrm{C}$, the crystallization peak began to appear. Only the characteristic peaks of magnesium oxide appeared at $600^{\circ} \mathrm{C}$, indicating that the alumina was still in the amorphous state. At $800^{\circ} \mathrm{C}$, two characteristic peaks of magnesium oxide and aluminum oxide clearly occurred, indicating that the aluminum oxide began to crystallize; however, the peak intensity was not high and the crystallization was incomplete. After calcination at $1000^{\circ} \mathrm{C}$, the characteristic peaks of aluminum oxide disappeared and were converted into aluminum-magnesium compounds. The characteristic peaks of magnesium oxide 


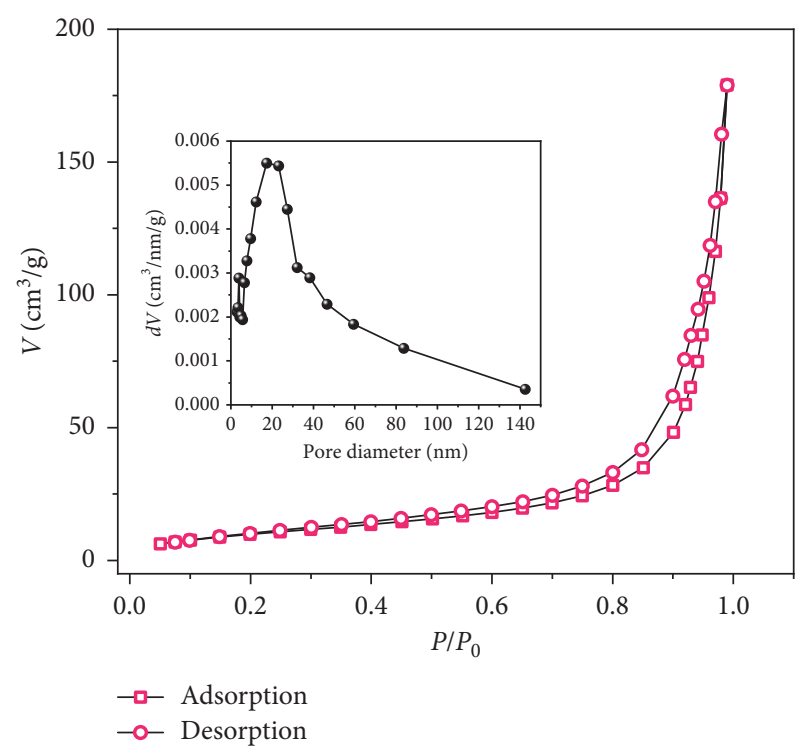

FIgURE 3: $\mathrm{N}_{2}$ adsorption-desorption isotherms of the FCT-1000-IV (inset: pore size distribution of the FCT-1000-IV).

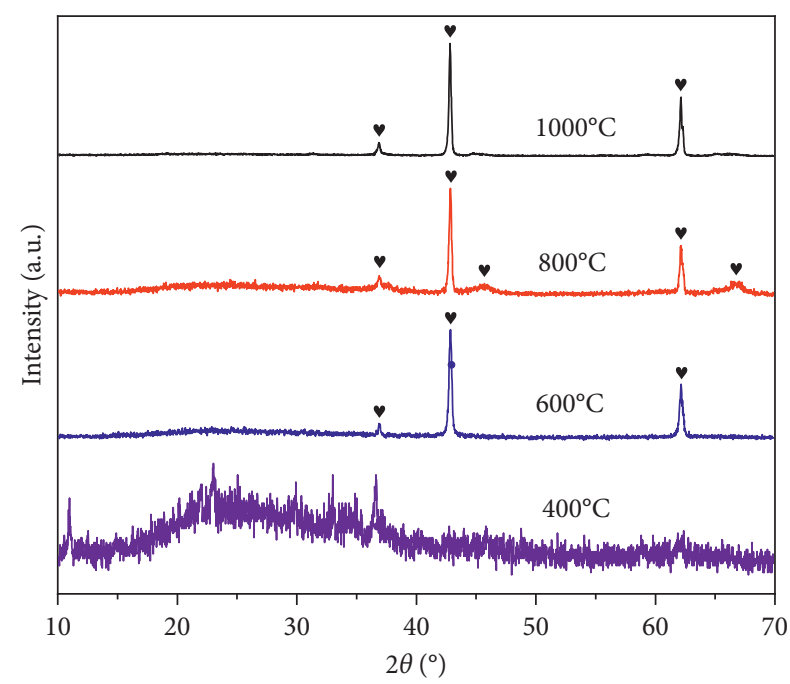

FIGURE 4: XRD patterns of the Mg-Al mixed oxide adsorbent prepared using different calcination temperatures $(\mathrm{Mg} / \mathrm{Al}$ molar ratio of $1: 2$ ).

also appeared. Increasing the calcining temperature has been reported to lead to decreased adsorption capacity of the adsorbent although the maximum investigated calcination temperature in such previous studies was only $850^{\circ} \mathrm{C}$ $[38,39]$. The literature contains no reports of an improvement in the adsorption performance after calcination at $1000^{\circ} \mathrm{C}$.

The FT-IR spectra of the Mg-Al mixed oxide adsorbent calcined at different temperatures are shown in Figure 5 (FCT-400-IV, FCT-600-IV, FCT-800-IV, and FCT-1000IV). As the calcining temperature increases, the peak intensity at $3466 \mathrm{~cm}^{-1}$ gradually decreases. However, after the calcining temperature increased to $1000^{\circ} \mathrm{C}$, the peak intensity again became stronger, and two new peaks appeared at 2926 and $2855 \mathrm{~cm}^{-1}$. These results suggest that the $\mathrm{Mg}$ - $\mathrm{Al}$

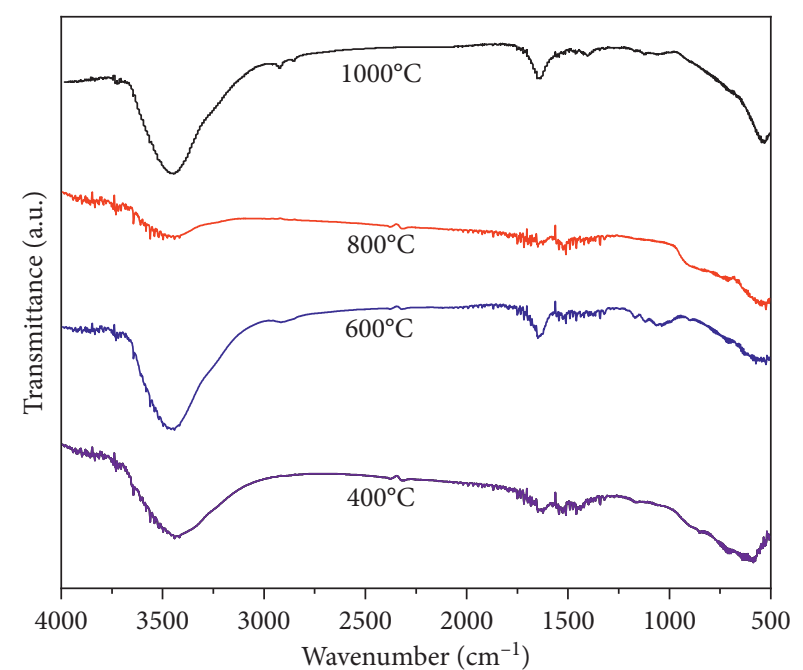

FIGURE 5: FT-IR spectra of the Mg-Al mixed oxide adsorbent using different calcination temperatures $(\mathrm{Mg} / \mathrm{Al}$ molar ratio of $1: 2)$.

mixed oxide calcined at $1000^{\circ} \mathrm{C}$ exhibits good adsorption performance because of this change. Therefore, the calcination temperature of $1000^{\circ} \mathrm{C}$ was used as the best adsorbent calcination temperature.

The effect of coexisting ions, including $\mathrm{Cl}^{-}, \mathrm{NO}_{3}{ }^{-}, \mathrm{SO}_{4}{ }^{2-}$, $\mathrm{HCO}_{3}^{-}, \mathrm{H}_{2} \mathrm{PO}_{4}^{-}, \mathrm{Na}^{+}$, and $\mathrm{K}^{+}$in the concentration range $0-0.7 \mathrm{mg} / \mathrm{L}$, was evaluated using a $50 \mathrm{mg} / \mathrm{L}$ fluoride solution to test the fluoride removal efficiency of the best product (Figure 6). With increasing ion concentration of $\mathrm{Cl}^{-}, \mathrm{NO}_{3}{ }^{-}$, and $\mathrm{SO}_{4}{ }^{2-}, \mathrm{Na}^{+}$and $\mathrm{K}^{+}$have little effect on the fluoride removal efficiency. However, when the concentration of $\mathrm{HCO}_{3}{ }^{-}$and $\mathrm{H}_{2} \mathrm{PO}_{4}{ }^{-}$is increased, the removal efficiency of fluoride decreases from 50 to $35 \%$. This behavior may be because the hydrolysis of $\mathrm{HCO}_{3}{ }^{-}$and $\mathrm{HPO}_{4}{ }^{-}$produces hydroxide ions, which increase the electrostatic repulsion in the solution, making it difficult for fluoride ions to adsorb at the adsorption sites. The results of the FCT-1000-IV defluoridation test in real water samples are shown in Figure 7. The results show that FCT-1000-IV still had good fluorine removal ability in real water samples.

\subsection{Optimum Conditions for the Removal of Fluoride}

3.2.1. Effect of $p H$ on the Adsorption Capacity. The effect of the $\mathrm{pH}$ value for defluoridation by the FCT-1000-IV at different $\mathrm{pH}$ values was investigated, as shown in Figure 8. The effect of $\mathrm{pH}$ on the adsorption capacity was characterized in the $\mathrm{pH}$ range from 2 to 11 . FCT-1000-IV reached maximum adsorption capacity at $\mathrm{pH}$ 6. The adsorption process was more favorable under acidic conditions than under alkaline conditions; however, the neutral conditions were most suitable for the adsorption process.

3.2.2. Effect of Contact Time on the Adsorption Capacity. The shaking time is an important factor affecting adsorption capacity. The adsorption behavior was studied as a function of contact time from 2 to $24 \mathrm{~h}$ with FCT-1000-IV at $30^{\circ} \mathrm{C}$ 


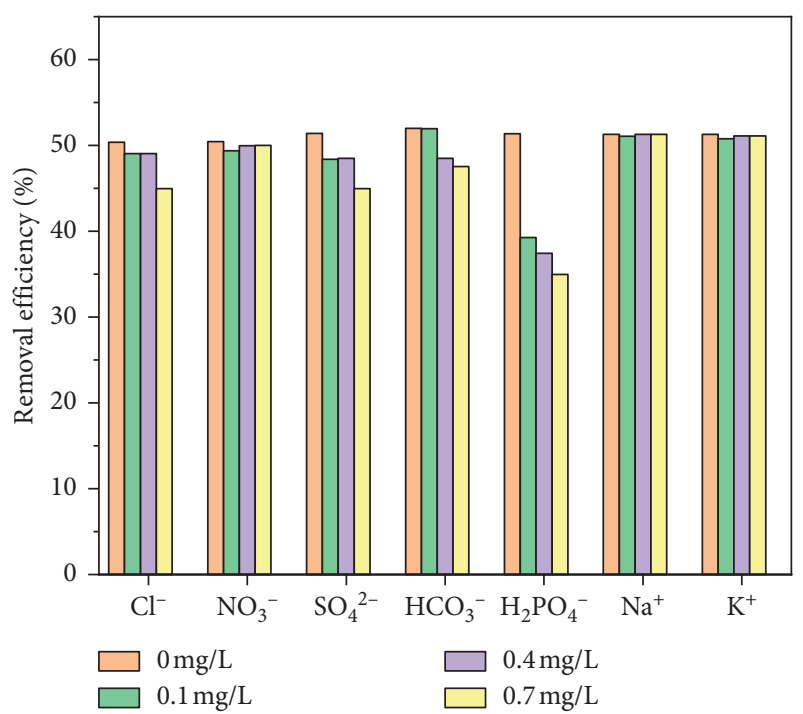

FIGURE 6: Effect of coexisting ions on fluoride removal efficiency of FCT-1000-IV (adsorbent dose: $0.5 \mathrm{~g} / \mathrm{L}$; initial concentration of $\mathrm{F}^{-}$: $50 \mathrm{mg} / \mathrm{L}$; adsorption time: $24 \mathrm{~h}$; temperature: $30^{\circ} \mathrm{C}$; $\mathrm{pH}$ : neutral conditions).

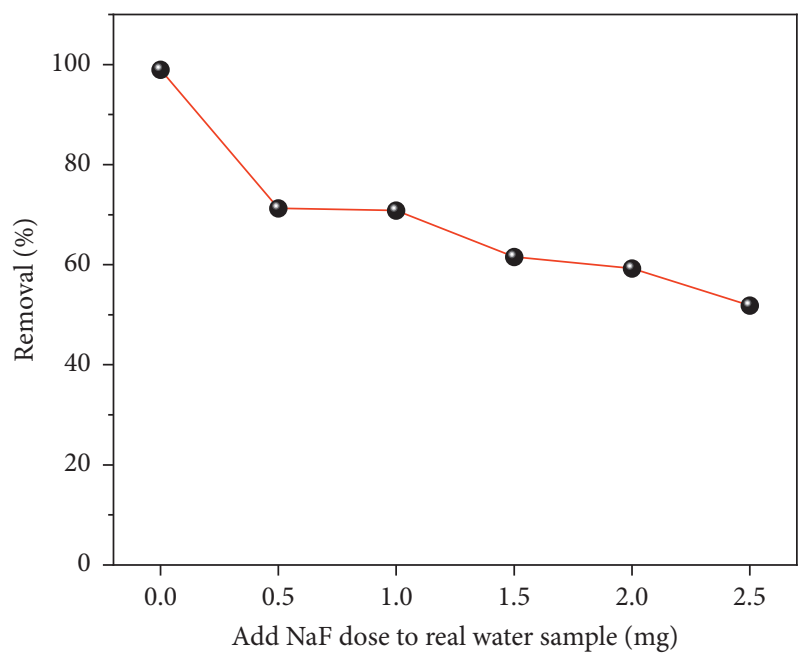

Figure 7: Fluoride removal from the real water samples using the FCT-1000-IV (adsorbent dose: $0.5 \mathrm{~g} / \mathrm{L}$; adsorption time: $24 \mathrm{~h}$; temperature: $\left.30^{\circ} \mathrm{C}\right)$.

(Figure 9). It is clear from the above results that the adsorption enhances with time and an equilibrium state is attained after its maximum capacity had been obtained. The fluoride removal rate increased rapidly at the beginning; however, the rate changed slowly with time beginning at $12 \mathrm{~h}$. The equilibrium time was $24 \mathrm{~h}$ for removal of fluoride from solution by FCT-1000-IV.

\subsubsection{Effect of Temperature on the Adsorption Capacity.} Fluoride removal was studied at different temperatures; the results are shown in Figure 10. The adsorption capacity clearly increases with increasing temperature. Thermal energy may exacerbate collisions between FCT-1000-IV particles, exposing more active sites. This effect demonstrates

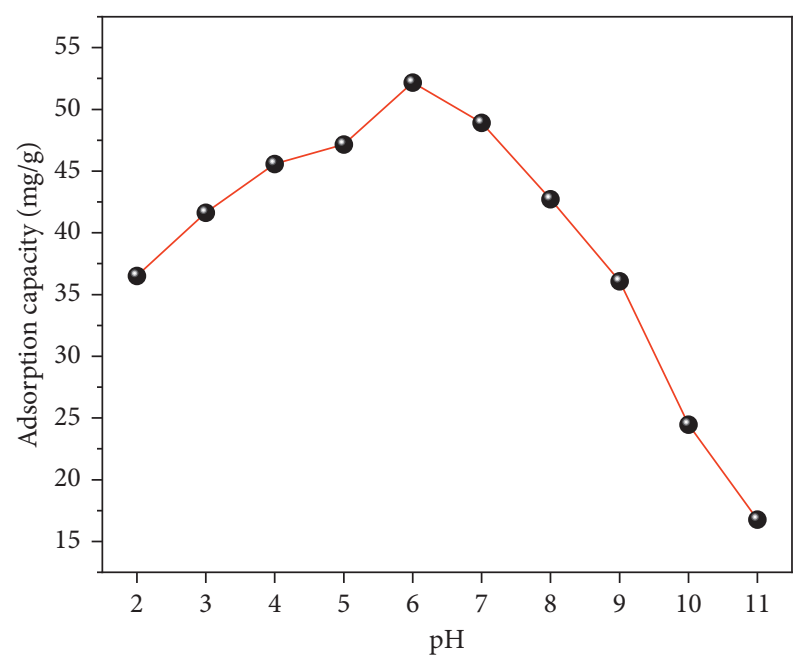

FIGURE 8: Effect of $\mathrm{pH}$ on the adsorption capacity of FCT-1000-IV to fluoride (adsorbent dose: $0.5 \mathrm{~g} / \mathrm{L}$; initial concentration of $\mathrm{F}^{-}$: $50 \mathrm{mg} / \mathrm{L}$; adsorption time: $24 \mathrm{~h}$; temperature: $30^{\circ} \mathrm{C} ; 2 \leq \mathrm{pH} \leq 11$ ).

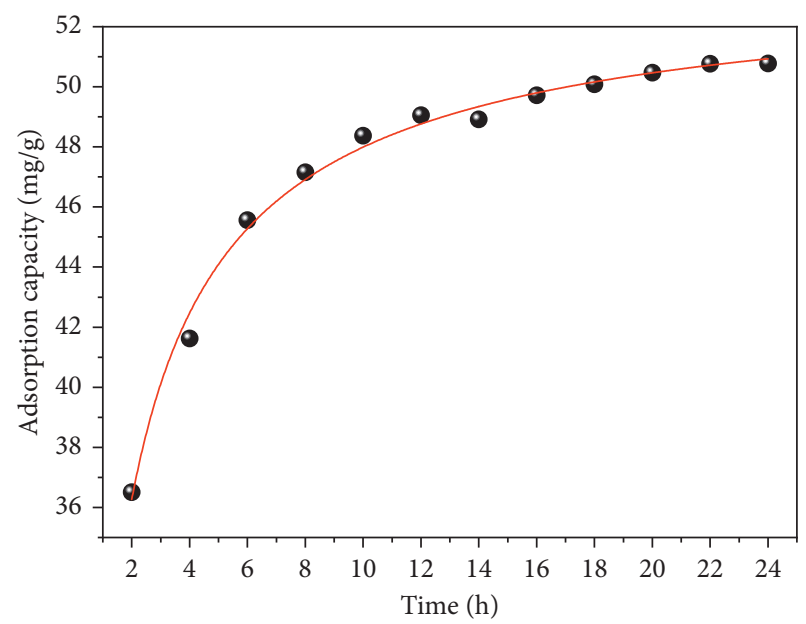

FIGURE 9: Effect of contact time on the fluoride adsorption capacity of FCT-1000-IV (adsorbent dose: $0.5 \mathrm{~g} / \mathrm{L}$; initial concentration of $\mathrm{F}^{-}: 50 \mathrm{mg} / \mathrm{L}$; adsorption time: $2-24 \mathrm{~h}$; temperature: $30^{\circ} \mathrm{C} ; \mathrm{pH}$ : neutral conditions).

that temperature is one of the factors that affect the adsorption capacity. This evidence indicates that the adsorption of fluoride on FCT-1000-IV particles was an endothermic process. However, the increase in temperature had little effect on the adsorption capacity; thus, the adsorption test was still carried out at simulated room temperature.

3.2.4. Effect of Initial Concentration on the Adsorption Capacity. The effect of the initial $\mathrm{F}^{-}$concentration on the $\mathrm{F}^{-}$ adsorption capacity and removal rate of FCT-1000-IV particles were studied with all other parameters kept constant (adsorbent dose: $0.05 \mathrm{~g}$, volume of solution: $100 \mathrm{~mL}$, temperature: $30^{\circ} \mathrm{C}$, contact time: $24 \mathrm{~h}$ ); the result is shown in Figure 11. In this observation, the removal rate decreased with increasing adsorption capacity. In high concentrations 


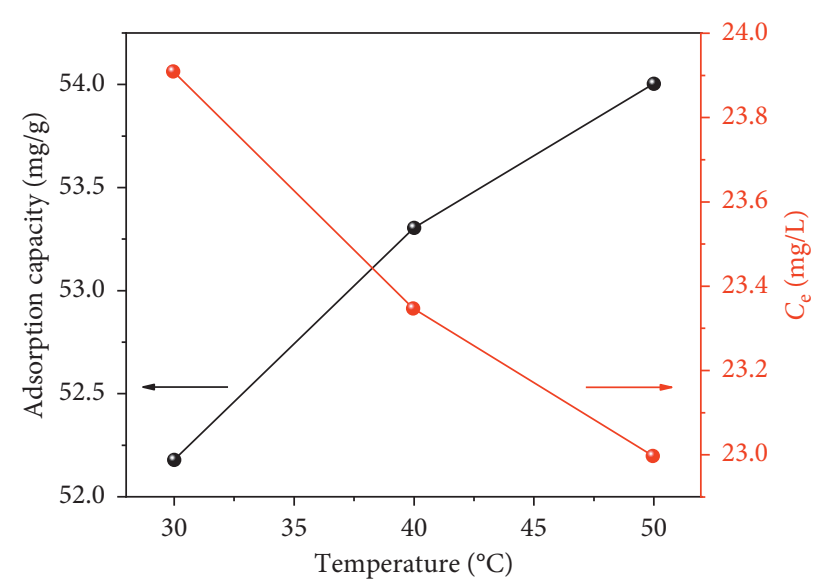

Figure 10: Effect of temperature on the fluoride adsorption capacity of FCT-1000-IV (adsorbent dose: $0.5 \mathrm{~g} / \mathrm{L}$; initial concentration of $\mathrm{F}^{-}: 50 \mathrm{mg} / \mathrm{L}$; adsorption time: $24 \mathrm{~h}$; temperature: $30-50^{\circ} \mathrm{C}$; $\mathrm{pH}$ : neutral conditions).

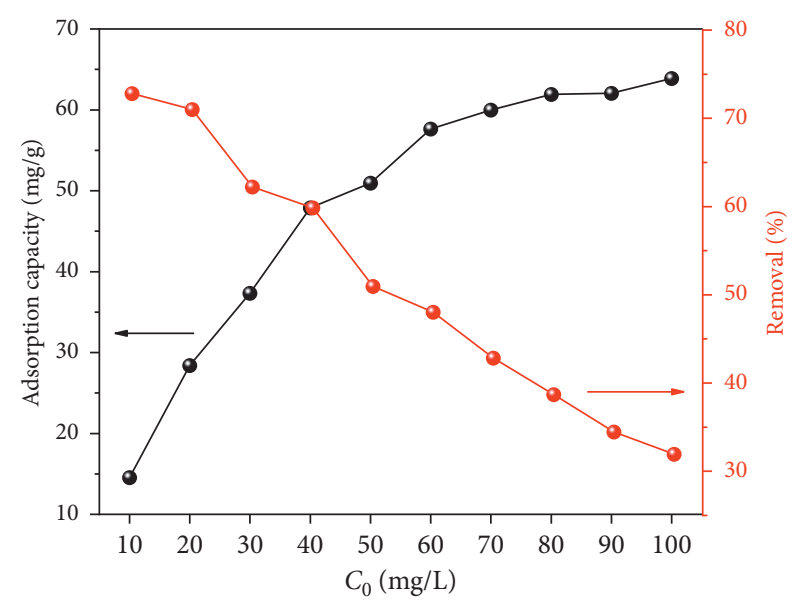

FIGURE 11: Effect of initial concentration on the fluoride adsorption capacity of FCT-1000-IV (adsorbent dose: $0.5 \mathrm{~g} / \mathrm{L}$; initial concentration of $\mathrm{F}^{-}: 10-100 \mathrm{mg} / \mathrm{L}$; adsorption time: $24 \mathrm{~h}$; temperature: $30^{\circ} \mathrm{C} ; \mathrm{pH}$ : neutral conditions).

of fluoride solution, more active sites of the adsorbent were occupied, resulting in a reduction of the removal rate. When the $C_{0}$ values reached $100 \mathrm{mg} / \mathrm{L}$, the adsorption capacity became $63.88 \mathrm{mg} / \mathrm{g}$ and then removal rate decreased to less than $32 \%$. At high-fluoride concentrations, the adsorption sites tend to saturate, leading to a decrease in removal rates. To ensure the high adsorption capacity of FCT-1000-IV, $0.05 \mathrm{~g}$ of adsorbent and a solution of $50 \mathrm{mg} / \mathrm{L}$ concentration were selected for the study.

3.3. Synergistic Interaction between $\mathrm{Mg}$ and $\mathrm{Al}$. To study the synergistic interaction between $\mathrm{Mg}$ and $\mathrm{Al}$, a $\mathrm{Mg}$ - $\mathrm{Al}$ mixed oxide adsorbent was prepared using a $\mathrm{Mg} / \mathrm{Al}$ molar ratio of $1: 2$ and a calcination temperature of $1000^{\circ} \mathrm{C}$. For comparison, a $\mathrm{Mg}$ oxide adsorbent and an $\mathrm{Al}$ oxide adsorbent were separately prepared under the same conditions. Figure 12 shows the adsorption capacity of fluoride by

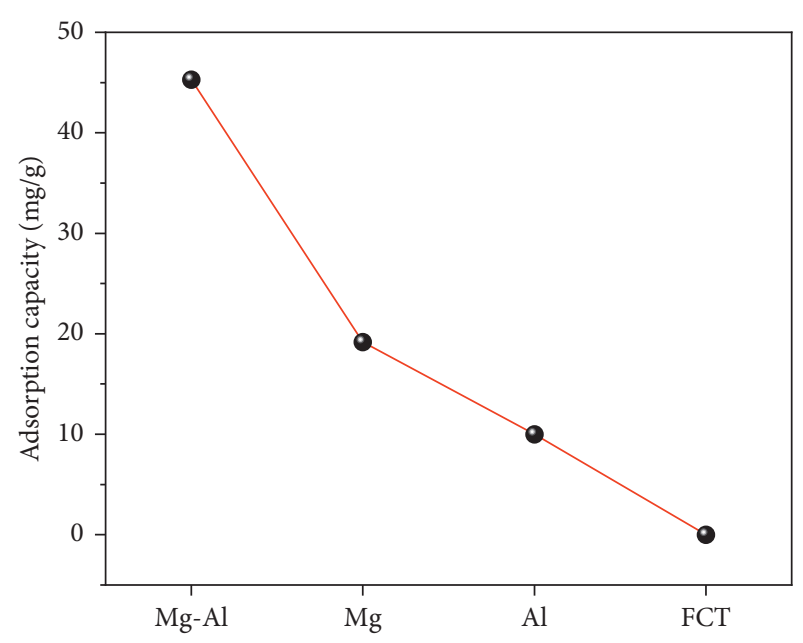

FIgURE 12: Comparison of fluoride removal ability of different media (adsorbent dose: $0.5 \mathrm{~g} / \mathrm{L}$; initial concentration of $\mathrm{F}^{-}: 50 \mathrm{mg} / \mathrm{L}$; adsorption time: $24 \mathrm{~h}$; temperature: $30^{\circ} \mathrm{C}$; $\mathrm{pH}$ : neutral conditions).

different media. The equilibrium adsorption capacity of the $\mathrm{Mg}$-Al mixed oxide adsorbent was $45.3 \mathrm{mg} / \mathrm{g}$ at an initial fluoride concentration of $50 \mathrm{mg} / \mathrm{L}$ and a sorbent dose of $0.5 \mathrm{~g} / \mathrm{L}$. The equilibrium adsorption capacities of the $\mathrm{Mg}$ oxide adsorbent and the $\mathrm{Al}$ oxide adsorbent were $19.2 \mathrm{mg} / \mathrm{g}$ and $10 \mathrm{mg} / \mathrm{g}$, respectively. However, free FCT was not effective for removing fluoride. In addition, the equilibrium adsorption capacity of the physical mixture of the Mg oxide adsorbent and the $\mathrm{Al}$ oxide adsorbent with a mass ratio of $\mathrm{Mg} / \mathrm{Al}$ of $1: 1$ is $17.2 \mathrm{mg} / \mathrm{g}$, which is also lower than the equilibrium adsorbent capacity of the $\mathrm{Mg}$ - $\mathrm{Al}$ mixed oxide adsorbent.

The XRD patterns of the Mg oxide, Al oxide, and MgAl mixed oxide are shown in Figure 13. The spectrum of magnesium oxide indicates the formation of facecentered cubic (FCC) magnesium oxide powder (JCPDS file No. 89-7746). The spectrum of the aluminum oxide shows that all the peaks are indexed to the cubic gamma alumina, in agreement with previous literature (JCPDS file No. 29-0063). The spectrum of the magnesium aluminum oxide shows that there are mainly two phases. One is still face-centered cubic magnesium oxide, and the other phase is newly formed $\mathrm{Mg}_{0.4} \mathrm{Al}_{2.4} \mathrm{O}_{4}$ (JCPDS file No. 83-0378).

The morphologies of the $\mathrm{Mg}$ oxide, $\mathrm{Al}$ oxide, and $\mathrm{Mg}-\mathrm{Al}$ mixed oxide prepared under the same conditions are shown in Figure 14. The $\mathrm{Mg}$ oxide assembled into a hollow tube with $0.1 \mu \mathrm{m}$ particles (Figure $14(\mathrm{a})$ ). We assumed that the removal of the FCT template after calcination caused this morphology. The morphology of the Al oxide was composed of interconnected rod-like structures with a large number of particles distributed on the surface (Figure 14(b)). The morphology of the $\mathrm{Mg}-\mathrm{Al}$ mixed oxide is shown in Figure 14(c). There are two main morphologies: a $0.1 \mu \mathrm{m}$ particle similar to the Mg oxide and a flaky curly strip. A new morphology was generated while the morphology of the magnesium oxide continued to exist, which is consistent with the XRD analysis results. As shown in the partial enlargement (Figure 14(d)), small particles are still distributed 


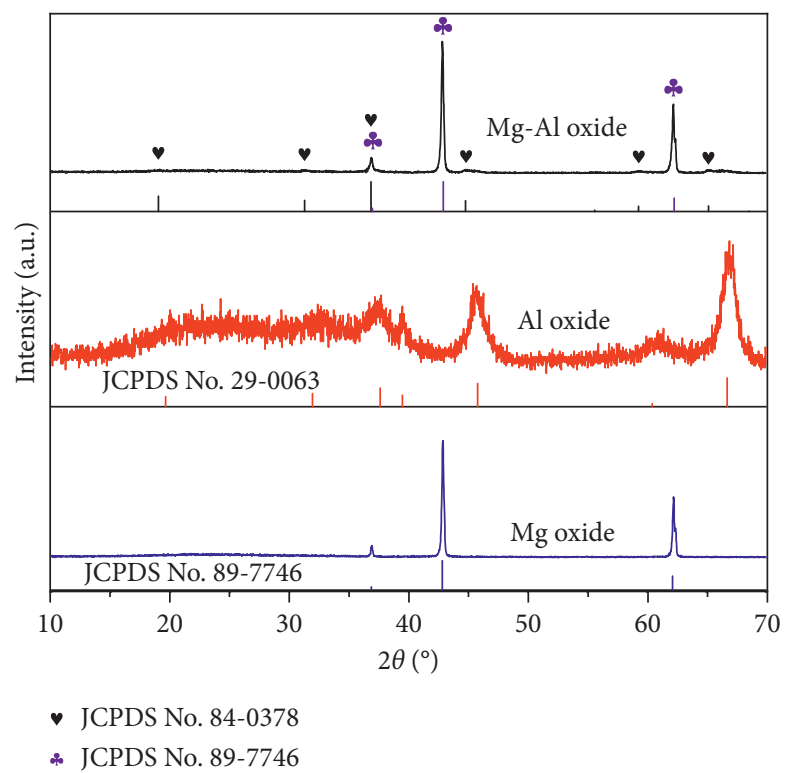

Figure 13: XRD patterns of the $\mathrm{Mg}$ oxide, $\mathrm{Al}$ oxide, and $\mathrm{Mg}$ - $\mathrm{Al}$ mixed oxide adsorbent calcined at $1000^{\circ} \mathrm{C}$.
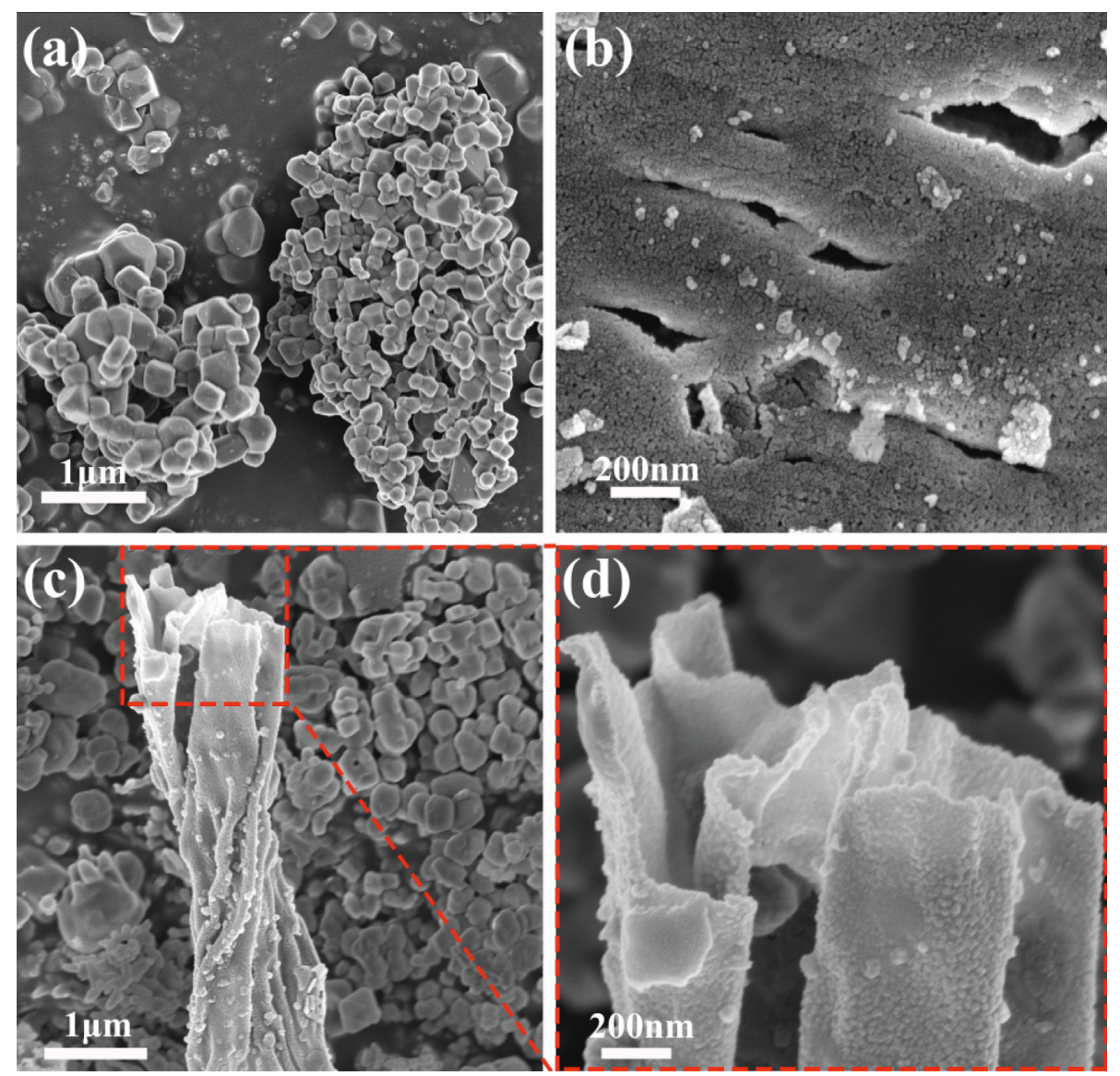

Figure 14: SEM images of (a) Mg oxide, (b) $\mathrm{Al}$ oxide, and (c, d) Mg-Al mixed oxide prepared under the same conditions.

on the flaky curly strip, which may be conducive to an increase in adsorption active sites.

The FT-IR spectra of the $\mathrm{Mg}$ oxide, $\mathrm{Al}$ oxide, and $\mathrm{Mg}$ - $\mathrm{Al}$ mixed oxide adsorbent are shown in Figure 15. The broad band at approximately $3450 \mathrm{~cm}^{-1}$ is attributed to the tensile vibration of the adsorbed water, and the peak at approximately $1640 \mathrm{~cm}^{-1}$ is attributed to the bending vibration of the $\mathrm{OH}$ group [30]. The two new peaks at 1120 and 


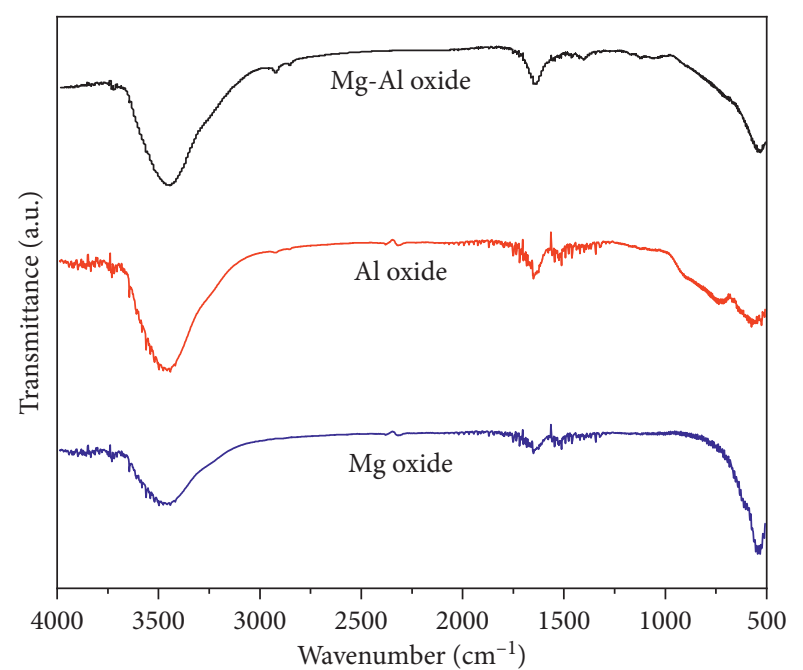

FIgURE 15: FT-IR spectra of the $\mathrm{Mg}$ oxide, $\mathrm{Al}$ oxide, and $\mathrm{Mg}-\mathrm{Al}$ mixed oxide adsorbent calcined at $1000^{\circ} \mathrm{C}$.

$1400 \mathrm{~cm}^{-1}$ in the spectrum of the Mg-Al mixed oxide are attributable to the bending vibration of the hydroxyl group on the bimetallic oxide [18]. Clearly, there are no peaks in the spectrum of the $\mathrm{Mg}$ oxide at 2850 and $2920 \mathrm{~cm}^{-1}$; however, the spectrum of the $\mathrm{Al}$ oxide begins to show two weak peaks, and the peak intensity of the $\mathrm{Mg}$ - $\mathrm{Al}$ mixed oxide is increased.

Based on the aforementioned analysis of the adsorption capacities, XRD, morphologies, and FT-IR spectra of the adsorbent, we inferred that the $\mathrm{Mg}$ - $\mathrm{Al}$ mixed oxide adsorbent is not a simple mixture of $\mathrm{Mg}$ oxide and $\mathrm{Al}$ oxide. A synergistic interaction occurs between the $\mathrm{Mg}$ and $\mathrm{Al}$ during the synthesis.

3.4. Adsorption Mechanism of the Mg-Al Mixed Adsorbent. The FT-IR spectra of the Mg-Al mixed oxide adsorbent before and after fluoride adsorption are shown in Figure 16. After fluoride adsorption, the bands at 3450 and $1640 \mathrm{~cm}^{-1}$ representing the hydroxyl groups shifted to 3462 and $1647 \mathrm{~cm}^{-1}$, respectively, indicating that the fluoride interacted with the hydroxyl groups on the $\mathrm{Mg}$ - $\mathrm{Al}$ mixed oxide adsorbent. Furthermore, the peak intensity of the $\mathrm{Mg}-\mathrm{Al}$ mixed oxide adsorbent at $1200,1400,2850$, and $2920 \mathrm{~cm}^{-1}$ was remarkably reduced after the removal of the fluoride. The spectrum of the adsorbed adsorbent showed a sharp peak at $3690 \mathrm{~cm}^{-1}$ compared with the spectrum of the original adsorbent because of the vibration of the physically adsorbed water [40].

To further investigate the adsorption mechanism of fluoride on the $\mathrm{Mg}$ - $\mathrm{Al}$ mixed oxide adsorbent, XPS analysis was applied to the adsorbent before and after adsorption. As shown in Figure 17(a), peaks of $\mathrm{Al} 2 \mathrm{p}, \mathrm{O} 1 \mathrm{~s}$, and $\mathrm{Mg}$ 1s were observed for the $\mathrm{Mg}$ - $\mathrm{Al}$ oxide adsorbent before and after use. After fluoride adsorption, a new binding energy related to photoelectrons in $\mathrm{F}$ 1s appeared at $685.8 \mathrm{eV}$, indicating that the fluoride was adsorbed onto the $\mathrm{Mg}$ - $\mathrm{Al}$ mixed oxide adsorbent. The F 1s spectrum shown in Figure 17(b) is divided into peaks located at approximately 685.2 and

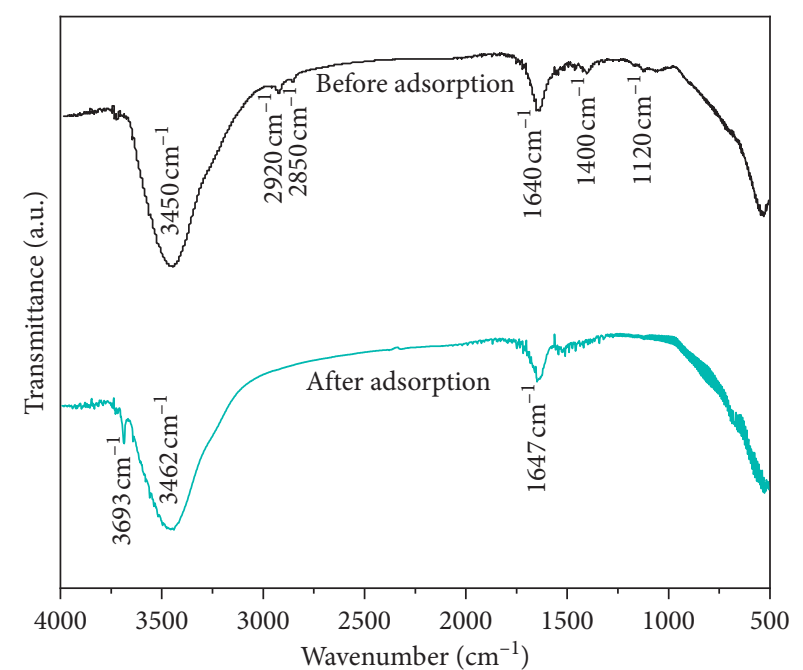

FIgURE 16: FT-IR spectra of the Mg-Al mixed oxide adsorbent before and after fluoride adsorption.

$685.5 \mathrm{eV}$. The peak of $685.2 \mathrm{eV}$ occupies $62.3 \%$ of the area attributed to the combination of fluorine atoms and magnesium (F-Mg) [41, 42], whereas the peak of $685.5 \mathrm{eV}$ accounts for $37.7 \%$ of the area due to the combination of fluorine atoms and aluminum (F-Al) $[43,44]$. The $\mathrm{O} 1 \mathrm{~s}$ spectrum before and after fluoride adsorption is divided into three peaks: adsorbed water $\left(\mathrm{H}_{2} \mathrm{O}\right)$, metal oxide $\left(\mathrm{O}^{2-}\right)$, and hydroxyl group bonded to metal $(\mathrm{M}-\mathrm{OH})$ [45]. After fluoride adsorption (Figures 17(c) and 17(d)), the surface hydroxyl groups of the adsorbent decreased from $37.8 \%$ to $11.2 \%$. In the coordination exchange, the fluoride ion is similar in radius to the hydroxyl group, and the $\mathrm{Mg}$ - $\mathrm{Al}$ metal ion releases the hydroxyl group to form a covalent bond with fluorine. The decrease in hydroxyl groups indicates that the hydroxyl group on the surface of the $\mathrm{Mg}-\mathrm{Al}$ mixed oxide adsorbent participates in the adsorption process of the fluoride, which is consistent with the results of the FT-IR analysis.

3.5. Reuse of Mg-Al Mixed Oxide Adsorbent. The regeneration study shows that the alkaline environment can regenerate the discharged metal oxide adsorbent [46]. The literature includes numerous studies on the removal of fluoride by various adsorbents, but studies of the reuse of metal oxides as sorbents are rare. In the present study, we observed that the defluorination ability of FCT-1000-IV showed a downward trend after 7 cycles (Figure 18). The ability to recycle adsorbents is economically beneficial.

\section{Conclusions}

A novel Mg-Al mixed oxide adsorbent was synthesized by dipping abiological template in a magnesium chloride and aluminum chloride solution at room temperature. When the FCT was dipped into a solution with $\mathrm{Mg} / \mathrm{Al}$ in a molar ratio of $1: 2$, the sample with the best adsorption performance was obtained after calcination at $1000^{\circ} \mathrm{C}$. The Langmuir adsorption capacity was $53 \mathrm{mg} / \mathrm{g}$. A synergistic 


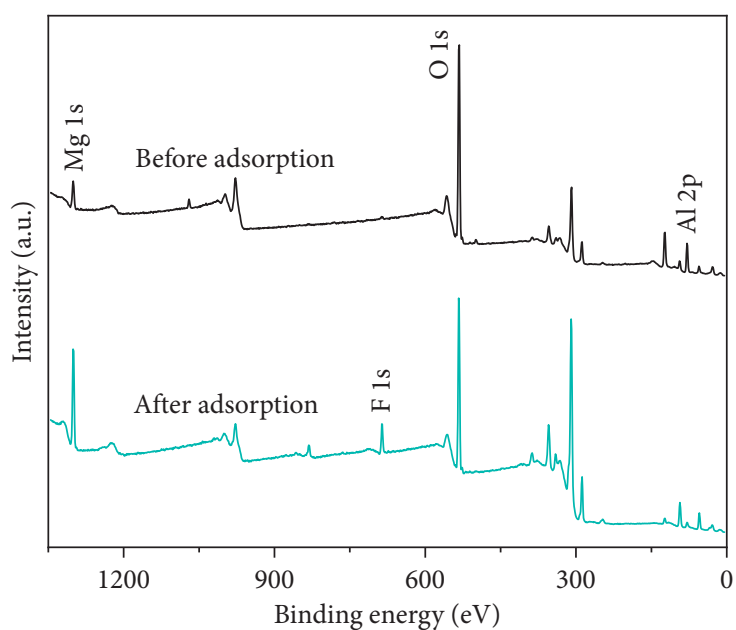

(a)

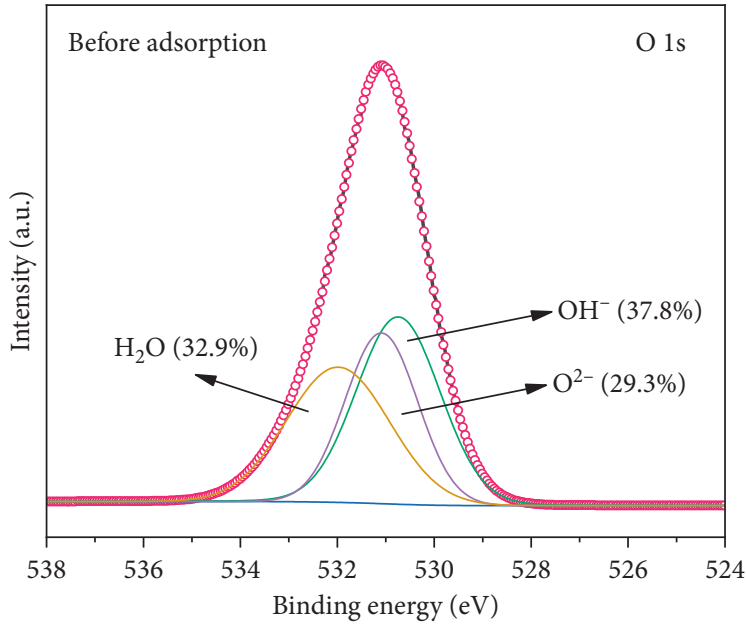

(c)

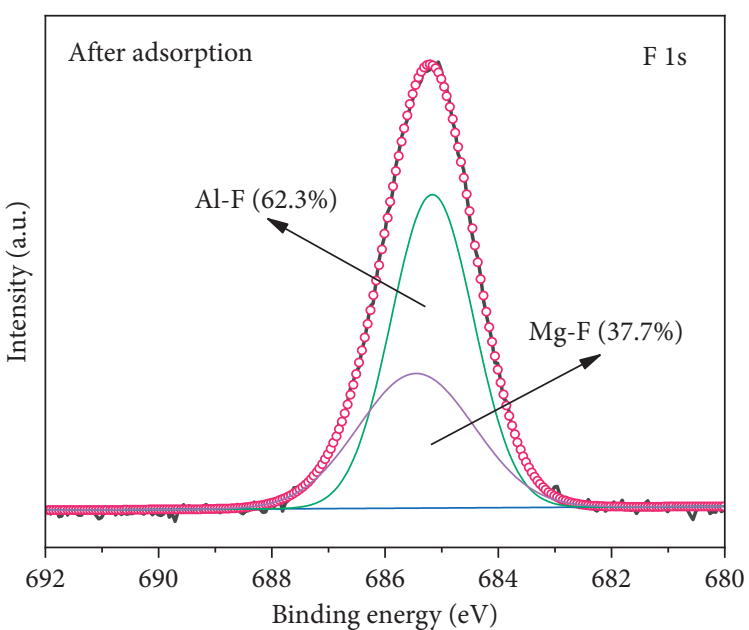

(b)

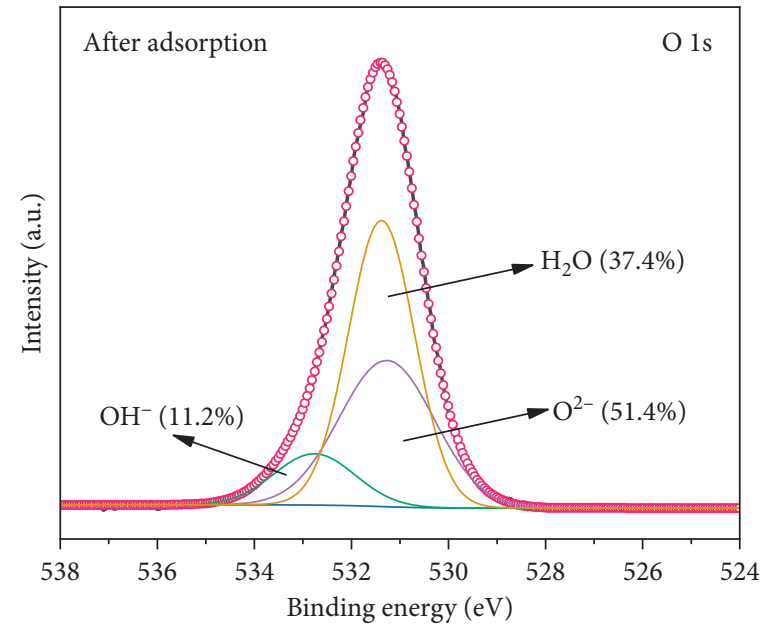

(d)

Figure 17: (a) XPS spectra of the Mg-Al mixed oxide adsorbent before and after fluoride adsorption; (b) F 1s spectra of the Mg-Al mixed oxide adsorbent after fluoride adsorption; (c) O 1s spectra of the $\mathrm{Mg}$-Al mixed oxide adsorbent before fluoride adsorption; (d) O 1s spectra of the $\mathrm{Mg}$ - $\mathrm{Al}$ oxide adsorbent after fluoride adsorption.

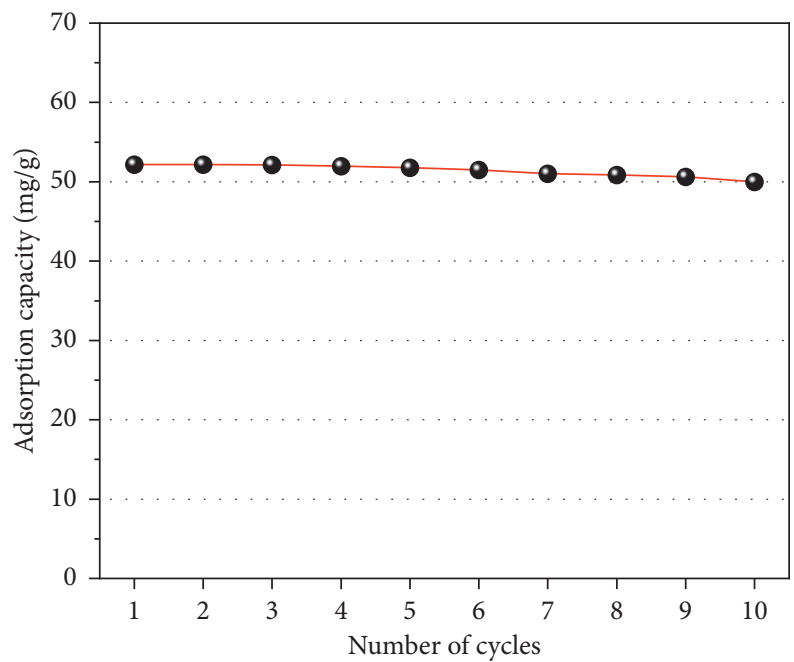

Figure 18: Adsorption capacity as a function of cycle number for the $\mathrm{Mg}$ - $\mathrm{Al}$ mixed oxide adsorbent. 
interaction between $\mathrm{Mg}$ and $\mathrm{Al}$ in the $\mathrm{Mg}$ - $\mathrm{Al}$ mixed oxide adsorbent improves the fluoride adsorption capacity and leads to good resistance to interference by coexisting ions. The adsorbent exhibited ability to remove fluorine from real water samples. Good regeneration and reusability were demonstrated even after 7 cycles of use. FT-IR and XPS analyses indicated that the hydroxyl groups on the surface of the $\mathrm{Mg}$ - $\mathrm{Al}$ mixed oxide adsorbent played an important role in fluoride adsorption by ion exchange. The novel MgAl mixed oxide is therefore an effective and environmentally friendly adsorbent for the removal of fluoride from drinking water.

\section{Data Availability}

The data used to support the findings of this study are available from the corresponding author upon request.

\section{Conflicts of Interest}

The authors declare that they have no conflicts of interest.

\section{Acknowledgments}

This work was supported by the Shandong Natural Science Foundation (grant number ZR2018LE003). We thank American Journal Experts (AJE) for English language editing. Thank are due to my family for supporting me during the experiment and writing.

\section{References}

[1] F. G. Omenetto and D. L. Kaplan, "New opportunities for an ancient material," Science, vol. 329, no. 5991, pp. 528-531, 2010.

[2] L. Liu, Y. Guo, Y. Wang, X. Yang, S. Wang, and H. Guo, "Hollow $\mathrm{NiO}$ nanotubes synthesized by bio-templates as the high performance anode materials of lithium-ion batteries," Electrochimica Acta, vol. 114, pp. 42-47, 2013.

[3] B. Bai, P. Wang, L. Wu, L. Yang, and Z. Chen, "A novel yeast bio-template route to synthesize $\mathrm{Cr}_{2} \mathrm{O}_{3}$ hollow microspheres," Materials Chemistry and Physics, vol. 114, no. 1, pp. 26-29, 2009.

[4] M. J. Abedin, L. Liepold, P. Suci, M. Young, and T. Douglas, "Synthesis of a cross-linked branched polymer network in the interior of a protein cage," Journal of the American Chemical Society, vol. 131, no. 12, pp. 4346-4354, 2009.

[5] X. Huang, J. Zhang, Z. Liu et al., "Facile preparation and microwave absorption properties of porous hollow $\mathrm{BaFe}_{12} \mathrm{O}_{19} / \mathrm{CoFe}_{2} \mathrm{O}_{4}$ composite microrods," Journal of Alloys and Compounds, vol. 648, pp. 1072-1075, 2015.

[6] L. Zhou, Z. Li, Z. Liu, M. Yin, J. Ren, and X. Qu, "One-step nucleotide-programmed growth of porous upconversion nanoparticles: application to cell labeling and drug delivery," Nanoscale, vol. 6, no. 3, pp. 1445-1452, 2014.

[7] Y. Le, D. Guo, B. Cheng, and J. Yu, "Bio-template-assisted synthesis of hierarchically hollow $\mathrm{SiO}_{2}$ microtubes and their enhanced formaldehyde adsorption performance," Applied Surface Science, vol. 274, pp. 110-116, 2013.

[8] B. Spittle, "Neurotoxic effects of fluoride," Fluoride, vol. 44, no. 3, pp. 117-124, 2011.
[9] W. H. Organization, Guidelines for Drinking-Water Quality: Recommendations, World Health Organization, Geneva, Switzerland, 2004.

[10] B. Nayak, M. M. Roy, B. Das et al., "Health effects of groundwater fluoride contamination," Clinical Toxicology, vol. 47, no. 4, pp. 292-295, 2009.

[11] P. Mondal and S. George, "A review on adsorbents used for defluoridation of drinking water," Reviews in Environmental Science and Bio/Technology, vol. 14, no. 2, pp. 195-210, 2015.

[12] Z. Ma, Q. Zhang, X. Weng et al., "Fluoride ion adsorption from wastewater using magnesium (II), aluminum (III) and titanium (IV) modified natural zeolite: kinetics, thermodynamics, and mechanistic aspects of adsorption," Journal of Water Reuse and Desalination, vol. 8, no. 4, pp. 479-489, 2018.

[13] N. Nasseh, L. Taghavi, B. Barikbin, and A. R. Harifi-Mood, "The removal of $\mathrm{Cr}(\mathrm{VI})$ from aqueous solution by almond green hull waste material: kinetic and equilibrium studies," Journal of Water Reuse and Desalination, vol. 7, no. 4, pp. 449-460, 2017.

[14] N. Rani, B. Singh, and T. Shimrah, "Chromium (VI) removal from aqueous solutions using Eichhornia as an adsorbent," Journal of Water Reuse and Desalination, vol. 7, no. 4, pp. 461-467, 2017.

[15] D. Tang, Y. Zhao, Y. Wang et al., "Defluorination from aqueous solution by Ti(IV)-modified granular activated carbon," Desalination and Water Treatment, vol. 54, no. 12, pp. 3432-3443, 2015.

[16] N. M. Zúñiga-Muro, A. Bonilla-Petriciolet, D. I. MendozaCastillo, H. E. Reynel-Ávila, and J. C. Tapia-Picazo, "Fluoride adsorption properties of cerium-containing bone char," Journal of Fluorine Chemistry, vol. 197, pp. 63-73, 2017.

[17] Y. Duan, C. Wang, X. Li, and W. Xu, "Fluoride adsorption properties of three modified forms of activated alumina in drinking water," Journal of Water and Health, vol. 12, no. 4, pp. 715-721, 2014.

[18] S. B. Deng, H. Liu, W. Zhou, J. Huang, and G. Yu, "Mn-Ce oxide as a high-capacity adsorbent for fluoride removal from water," Journal of Hazardous Materials, vol. 186, no. 2-3, pp. 1360-1366, 2011.

[19] J. Qiao, Z. Cui, Y. Sun, Q. Hu, and X. Guan, "Simultaneous removal of arsenate and fluoride from water by Al-Fe (hydr) oxides," Frontiers of Environmental Science and Engineering, vol. 8, no. 2, pp. 169-179, 2014.

[20] W. Zhao, Y. Chen, W. Zhang, J. Wang, C. Hu, and W. He, "Synthesis, performance, and mechanism of magnesiumiron-aluminum trimetal composite as an adsorbent for fluoride removal in water treatment," The Canadian Journal of Chemical Engineering, vol. 94, no. 12, pp. 2289-2297, 2016.

[21] X. Dou, D. Mohan, C. U. Pittman, and S. Yang, "Remediating fluoride from water using hydrous zirconium oxide," Chemical Engineering Journal, vol. 198-199, pp. 236-245, 2012.

[22] C. Yang, L. Gao, Y. Wang, X. Tian, and S. Komarneni, "Fluoride removal by ordered and disordered mesoporous aluminas," Microporous and Mesoporous Materials, vol. 197, pp. 156-163, 2014.

[23] T. L. Yami, J. Du, L. R. Brunson, J. F. Chamberlain, D. A. Sabatini, and E. C. Butler, "Life cycle assessment of adsorbents for fluoride removal from drinking water in East Africa," The International Journal of Life Cycle Assessment, vol. 20, no. 9, pp. 1277-1286, 2015.

[24] W. Yang, S. Tian, Q. Tang, L. Chai, and H. Wang, "Fungus hyphae-supported alumina: an efficient and reclaimable 
adsorbent for fluoride removal from water," Journal of Colloid and Interface Science, vol. 496, pp. 496-504, 2017.

[25] Y. Liu, S. Wang, Q. Fan, Y. Liu, and W. Zhou, "Adsorption of fluoride from aqueous solution on supported $\mathrm{Fe} / \gamma-\mathrm{Al}_{2} \mathrm{O}_{3}$ adsorbent prepared by ultrasonic-assisted technique," $D e$ salination and Water Treatment, vol. 100, pp. 67-74, 2017.

[26] J. Kang, B. Li, J. Song et al., "Defluoridation of water using calcined magnesia/pullulan composite," Chemical Engineering Journal, vol. 166, no. 2, pp. 765-771, 2011.

[27] Z. Jin, Y. Jia, K.-S. Zhang et al., "Effective removal of fluoride by porous $\mathrm{MgO}$ nanoplates and its adsorption mechanism," Journal of Alloys and Compounds, vol. 675, pp. 292-300, 2016.

[28] U. Sabu, M. Rashad, G. Logesh, K. Kumar, M. Lodhe, and M. Balasubramanian, "Development of biomorphic alumina using egg shell membrane as bio-template," Ceramics International, vol. 44, no. 5, pp. 4615-4621, 2018.

[29] G. Zhang, T. Zhang, B. Li et al., "Facile synthesis of $\mathrm{TiO}_{2}$ hierarchical tubes with enhanced photocatalytic activity," Materials Research Bulletin, vol. 94, pp. 247-256, 2017.

[30] H. Liu, S. B. Deng, Z. J. Li, G. Yu, and J. Huang, "Preparation of Al-Ce hybrid adsorbent and its application for defluoridation of drinking water," Journal of Hazardous Materials, vol. 179, no. 1-3, pp. 424-430, 2010.

[31] M. Wang, X. Yu, C. Yang et al., "Removal of fluoride from aqueous solution by $\mathrm{Mg}-\mathrm{Al}-\mathrm{Zr}$ triple-metal composite," Chemical Engineering Journal, vol. 322, pp. 246-253, 2017.

[32] Z. Yu, C. Xu, K. Yuan et al., "Template-free synthesis of $\mathrm{MgO}$ mesoporous nanofibers with superior adsorption for fluoride and Congo red," Ceramics International, vol. 44, no. 8, pp. 9454-9462, 2018.

[33] D. Kang, X. Yu, S. Tong et al., "Performance and mechanism of $\mathrm{Mg} / \mathrm{Fe}$ layered double hydroxides for fluoride and arsenate removal from aqueous solution," Chemical Engineering Journal, vol. 228, pp. 731-740, 2013.

[34] Y.-X. Zhang and Y. Jia, "Preparation of porous alumina hollow spheres as an adsorbent for fluoride removal from water with low aluminum residual," Ceramics International, vol. 42, no. 15, pp. 17472-17481, 2016.

[35] W. Ma, N. Zhao, G. Yang, L. Tian, and R. Wang, "Removal of fluoride ions from aqueous solution by the calcination product of $\mathrm{Mg}$-Al-Fe hydrotalcite-like compound," Desalination, vol. 268, no. 1-3, pp. 20-26, 2011.

[36] H. Jin, Z. Ji, J. Yuan et al., "Research on removal of fluoride in aqueous solution by alumina-modified expanded graphite composite," Journal of Alloys and Compounds, vol. 620, pp. 361-367, 2015.

[37] K. S. W. Sing, "Reporting physisorption data for gas/solid systems with special reference to the determination of surface area and porosity (Recommendations 1984)," Pure and Applied Chemistry, vol. 57, no. 4, pp. 603-619, 1985.

[38] L. Lv, J. He, M. Wei, D. Evans, and X. Duan, "Factors influencing the removal of fluoride from aqueous solution by calcined $\mathrm{Mg}-\mathrm{Al}-\mathrm{CO}_{3}$ layered double hydroxides," Journal of Hazardous Materials, vol. 133, no. 1-3, pp. 119-128, 2006.

[39] X. Wu, Y. Zhang, X. Dou, and M. Yang, "Fluoride removal performance of a novel Fe-Al-Ce trimetal oxide adsorbent," Chemosphere, vol. 69, no. 11, pp. 1758-1764, 2007.

[40] J. Wang, D. Kang, X. Yu, M. Ge, and Y. Chen, "Synthesis and characterization of Mg-Fe-La trimetal composite as an adsorbent for fluoride removal," Chemical Engineering Journal, vol. 264, pp. 506-513, 2015.

[41] Z. Jin, Y. Jia, K.-S. Zhang et al., "Effective removal of fluoride by porous $\mathrm{MgO}$ nanoplates and its adsorption mechanism," Journal of Alloys and Compounds, vol. 675, pp. 292-300, 2016.
[42] L.-X. Li, D. Xu, X.-Q. Li, W.-C. Liu, and Y. Jia, "Excellent fluoride removal properties of porous hollow $\mathrm{MgO}$ microspheres," New Journal of Chemistry, vol. 38, no. 11, pp. 5445-5452, 2014.

[43] T. Skapin, Z. Mazej, A. Makarowicz et al., "Aluminium(III) fluoride originating from decomposition of hydrazinium fluoroaluminate(III) under oxidative conditions: syntheses, $\mathrm{X}$-ray photoelectron spectroscopy and some catalytic reactions," Journal of Fluorine Chemistry, vol. 132, no. 10, pp. 703-712, 2011.

[44] W.-X. Gong, J.-H. Qu, R.-P. Liu, and H.-C. Lan, "Effect of aluminum fluoride complexation on fluoride removal by coagulation," Colloids and Surfaces A: Physicochemical and Engineering Aspects, vol. 395, pp. 88-93, 2012.

[45] J. He, K. Chen, X. Cai et al., "A biocompatible and novellydefined Al-HAP adsorption membrane for highly effective removal of fluoride from drinking water," Journal of Colloid and Interface Science, vol. 490, pp. 97-107, 2017.

[46] U. Kumari, S. K. Behera, and B. C. Meikap, "A novel acid modified alumina adsorbent with enhanced defluoridation property: kinetics, isotherm study and applicability on industrial wastewater," Journal of hazardous Materials, vol. 365, pp. 868-882, 2019. 

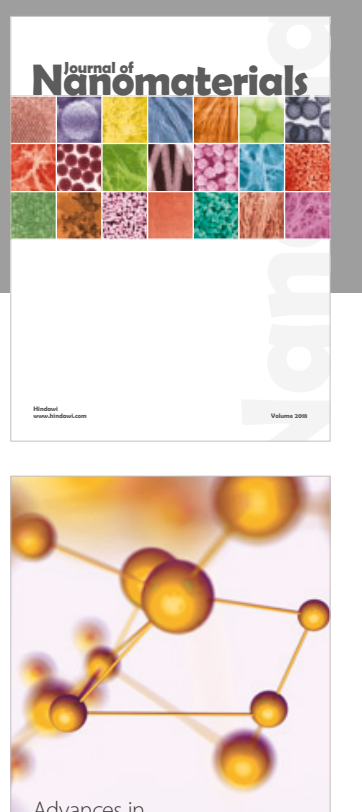

Physical Chemistry
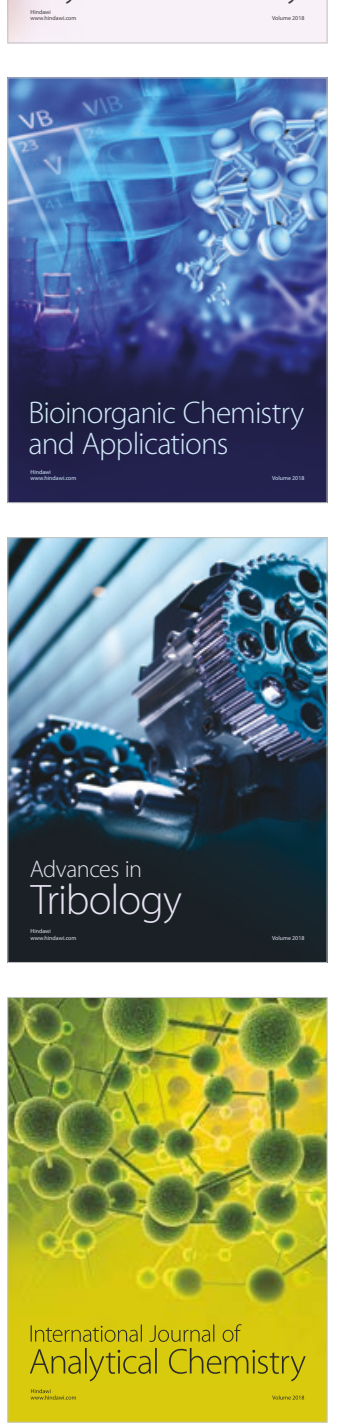

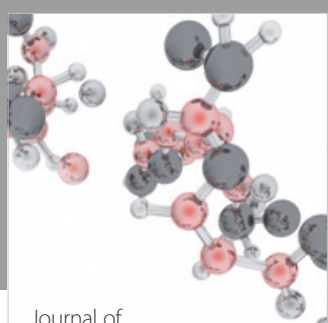

Analytical Methods

in Chemistry

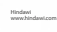

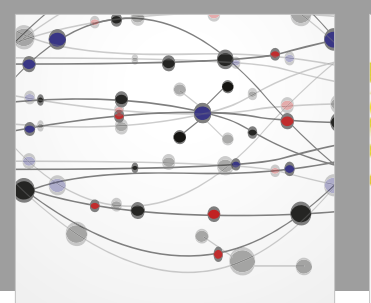

The Scientific World Journal

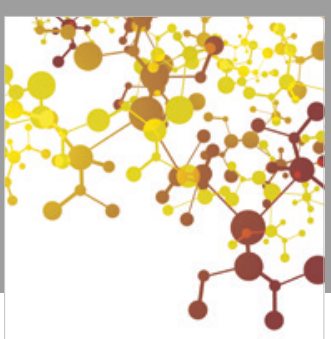

Journal of

Applied Chemistry
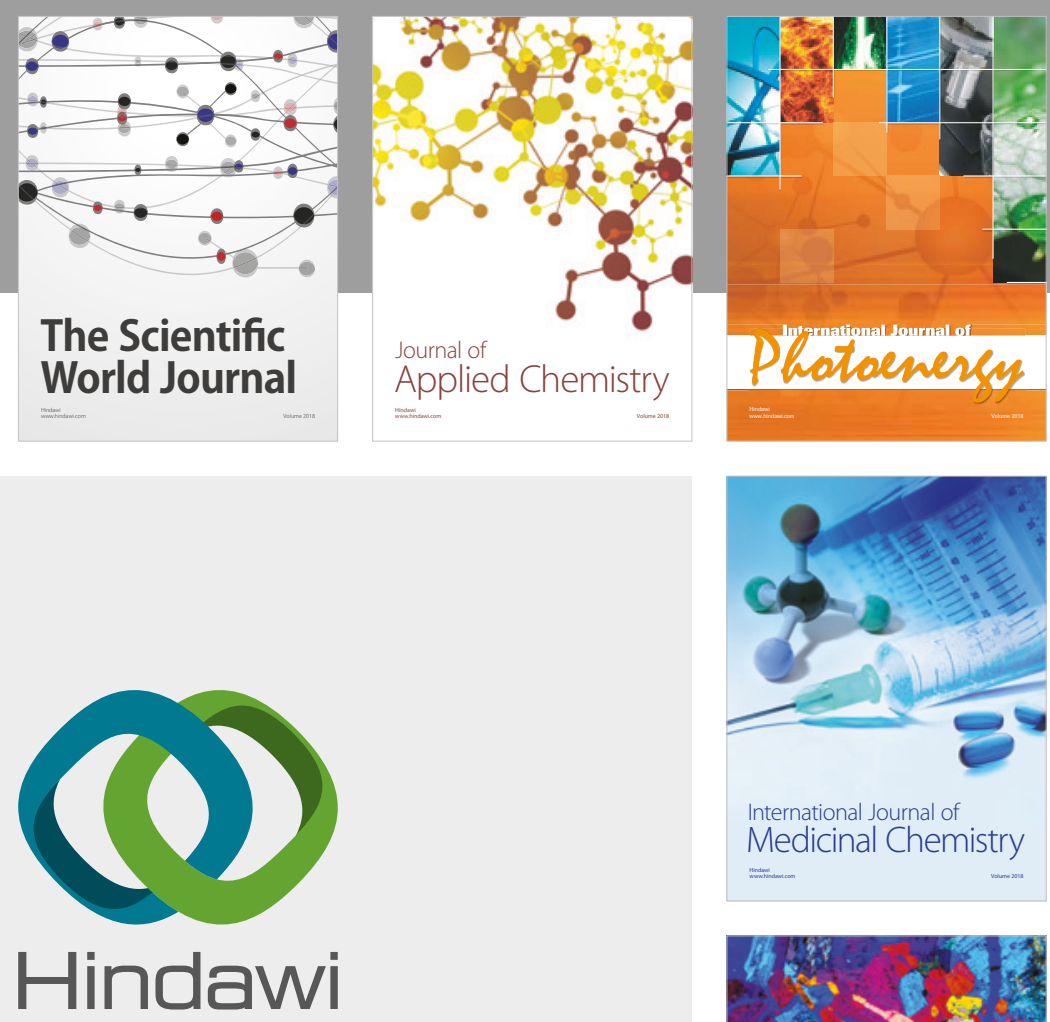

Submit your manuscripts at

www.hindawi.com
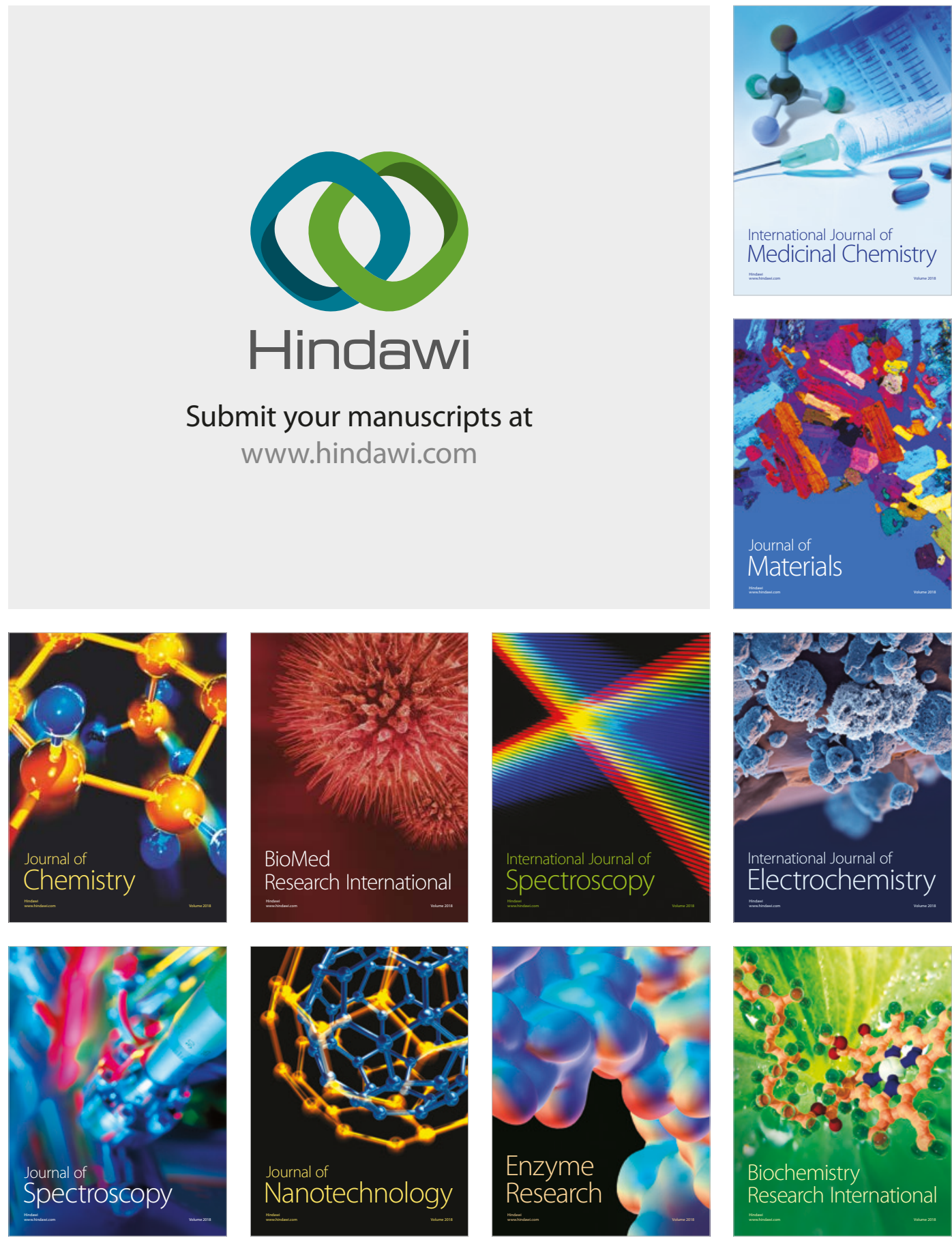
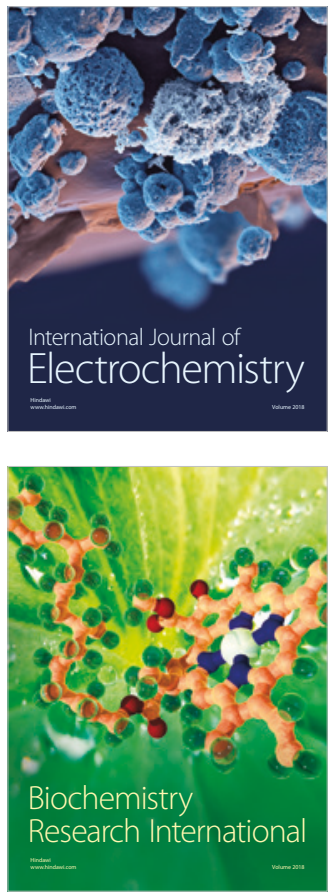